Social Work \& Education

(C) SW\&E, 2018

Pihovskyi, M. (2018). Соціальна відповідальність фахівця соціальної сфери як вагомий чинник результативності його професійної діяльності, Social Work and Education, Vol. 5, No. 4., pp. 56-65. DOI: 10.25128/2520-6230.18.4.5

\title{
СОЦАЛЬНА ВІДПОВІДАЛЬНІСТЬ ФАХІВЦЯ СОЦІАЛЬНОЇ СФЕРИ ЯК ВАГОМИЙ ЧИННИК РЕЗУЛЬТАТИВНОСТІ ЙОГО ПРОФЕСІЙНОЇ ДІЯЛЬНОСТІ
}

Mykola Pihovskyi,

Ph.D. student of Department of Social Pedagogy and Social Work Ternopil National Volodymyr Hnatyuk Pedagogical University Ternopil, Ukraine mpigovskiy@gmail.com

ORCID: 0000-0003-1972-0959

\section{Микола Піговський,} аспірант кафедри соиіальноі педагогіки і сочіальної роботи Тернопільський національний педагогічний університет імені Володимира Гнатюка м. Тернопіль, Украӥна

УДК 316.6

DOI: $10.25128 / 2520-6230.18 .4 .5$

Article history:

Received: October 08, 2018

1st Revision: November 18, 2018

Accepted: December 30, 2018
АНОТАЦЯ. У статті узагальнено науковий матеріал про відповідальність у цілому та соціальну відповідальність фахівця соціальної сфери зокрема. Зазначено, що соціальна сфера, задовольняючи потреби населення в освіті, охороні здоров'я, культурних цінностях, комунальному обслуговуванні тощо, все більше впливає на виробництво матеріальних багатств через прискорення науково-технічного прогресу, створення необхідних передумов для підвищення рівня зайнятості у суспільному виробництві та раціональному використанні кадрового потенціалу, забезпеченні розширеного відтворення робочої сили, удосконаленні структури вільного часу працюючих. Обгрунтовано важливість сформованості соціальної відповідальності фахівця соціальної сфери для виконання ним професійних обов'язків. На основі аналізу наукових досліджень проаналізовано зміст понять «відповідальність» (як усвідомлення сугі та значення діяльності, вчинків особи і їх наслідків для суспільства) та «соціальна відповідальність» (свідоме, добровільне виконання суб'єктами суспільних відносин приписів i соціальних норм). Вказано, що формування соціальної відповідальності фахівця соціальної сфери в Україні супроводжується рядом проблем. Схарактеризовано рівні (максимальний, мінімальний, припустимий й фактичний, а також мега-, макро-, мезо-, мікро-,), характерні ознаки, структуру (суб'єкт і об’єкт), види (неправову і правову (юридичну) соціальну відповідальність), принципи (гуманізму, прозорості, підзвітності, поміркованості у прийнятті рішень, патріотизму, обов'язку, духовності, професійної компетентності, творчої спрямованості, працелюбності) та форми (добровільну і примусову) реалізації соціальної відповідальності фахівця соціальної сфери. Обгрунтовано критерії (суб'єктивні й об'єктивні) і показники соціальної відповідальності. Визначено перспективи розвитку соціальної відповідальності як якості особистості фахівця соціальної сфери/

Ключові слова: відповідальність; соціальна відповідальність; соціальна сфера; фахівець; професійна діяльність; результативність. 


\section{Вступ}

Досягнення якісно нового стану сучасного суспільства неможливе без кардинального підвищення рівня відповідальності фахівців у різних сферах діяльності. Усвідомлення та розуміння власної відповідальності кожною особистістю у наш час $є$ суттєво важливим для всього соціуму, адже відповідальна професійна поведінка позначається на умовах життя й благополуччі людей та країни в цілому. Крім того, все гострішою стає проблема утвердження гуманістичних суспільних цінностей, світоглядної культури i формування високодуховної особистості, однією з найважливіших характеристик якої є іiі соціальна відповідальність. У зв'язку з цим, роботодавці переглядають своє ставлення до персоналу, який визнається однією з головних конкурентних переваг організації (служби, компанії) на ринку праці (Амоша, 2011, с. 124).

Основні аспекти соціальної відповідальності відображено в Концепції національної стратегї соціальної відповідальності бізнесу в Україні і Міжнародному HR-стандарті SA 80001997 «Соціальна відповідальність». Проте слід зауважити, що процес формування соціальної відповідальності фахівця $є$ доволі непростим. Складність означеного процесу обумовлюється насамперед тим, що в умовах військових дій на сході України та окупації Криму, реструктуризації економіки, реформування багатьох галузей виробництва й обслуговування населення, не визначеними залишаються як основні характеристики соціальної відповідальності фахівця, так і механізми іï формування (Кузьмін, 2016, с. 5).

Відрадно, що проблема соціальної відповідальності громадянина перед державою, держави перед громадянином, особи (в тому числі - фахівця) за свої вчинки та результати діяльності перебуває у полі зацікавлення науковців. Так, зміст поняття «соціальна відповідальність» досліджували Н. Вацик, В. Грищук, О. Кузьмін, О. Пирог, С. Романишин, Л. Чернобай та ін.; діагностику стану та аналіз перспектив розвитку соціальної відповідальності в Україні здійснили О. Новікова, М. Дейч, О. Панькова та ін.; соціальну відповідальність в контексті розвитку людського потенціалу вивчали О. Амоша, О. Новікова, І. Савченко та ін.; оцінюванню рівнів соціальної відповідальності присвячено праці Д. Баюри, В. Білявського, В. Свтушенка, В. Македон та ін.; механізми та напрями формування соціальної відповідальності схарактеризовано в роботах Л. Будьонної, Л. Грицини, А. Колот та ін. Проте, незважаючи на таке розмаїття напрямів вивчення соціальної відповідальності, багато питань цієї складної теми залишаються малодослідженими. Насамперед це стосується змісту соціальної відповідальності фахівців різних сфер діяльності та механізмів ії формування.

Метою статті $\epsilon$ характеристика соціальної відповідальності як якості особистості та обгрунтування ii ролі у виконанні професійних обов'язків фахівцем соціальної сфери. Для досягнення поставленої мети виділено наступні завдання: розкрити зміст, дослідити структуру, визначити та схарактеризувати основні види соціальної відповідальності, висвітлити іiі значення у професійній діяльності фахівця соціальної сфери. 


\section{Методологія дослідження}

Оскільки серед факторів економічного зростання на перше місце у світі вийшов людський фактор, то визначальною у розвитку економіки, суспільства у цілому в XXI ст. стає саме соціальна сфера. Функціонування цієї сфери спрямоване на вдосконалення людини, розвиток іiі інтелектуальних і фізичних можливостей, забезпечення соціальних, духовних й культурних потреб (Амоша, 2011, с. 126). Соціальна відповідальність, незалежно від масштабу дослідження, визначається на глобальному, національному, регіональному та особистісному рівнях. Означені рівні розкривають зміст соціальної відповідальності через визначення проблем та умов існування людства у цілому, окремих соціальних спільнот і груп, конкретної особи, пошук шляхів розв’язання цих проблем завдяки соціальній інтеграції, спрямованій на забезпечення сталого розвитку незалежно від місця проживання та расової приналежності (Савченко, 2005, с. 55).

\section{Основна частина}

У сучасних наукових джерелах у найбільш загальному, концентрованому розумінні етимологія поняття «відповідальність» відображена як «обов’язок відповідати за щось, повинність ручатися за щось, зобов'язання звітувати про щось» (Шинкарук, 2002, с. 6). 3 точки зору психології відповідальність - це покладений на когось або взятий на себе обов'язок відповідати за певну ділянку роботи, справу, дії, вчинки, слова (Шинкарук, 2002, с. 7). У соціології відповідальність - це категорія, яка виражає свідоме ставлення особи до вимог суспільної необхідності, обов'язків, соціальних завдань, норм і цінностей. У менеджменті відповідальність - це положення, при якому особа, яка виконує якунебудь роботу, зобов'язана дати повний звіт про свої дії і прийняти на себе вину за можливі наслідки, які можуть наступити при виконанні (Шинкарук, 2002, с. 8). Соціальні педагоги трактують відповідальність як рису, яка концентрує усвідомлений особистістю суспільно значущий обов'язок, повинність у здійсненні морального вчинку (Звєрєва, 2012, с. 19). Ми розглядаємо відповідальність як здатність суб'єкта (людини, групи чи організації) адекватно відповідати за те, що йому (ій) доручено або за те, що він (вона) вирішив зробити самостійно.

Погоджуємось із В. Шинкарук, що відповідальність може бути обумовлена угодою, статусом (наприклад, відповідальність службової особи, спричиненою груповими, корпоративними, будь-якими іншими обов'язками, що наближає їі до розуміння підзвітності) і усвідомлюватися людиною як обов'язок, або ж обумовлюється внутрішньою потребою і усвідомлюється як покликання (Шинкарук, 2002, с. 19). На думку науковців, доцільно виокремити наступні поняття: відповідальний громадянин, відповідальний працівник, відповідальний учасник соціальних груп, відповідальний сім'янин, відповідальний споживач та відповідальний житель планети Земля. Наведені поняття відображають сутність й складові відповідальності особи (Вієвська, 2015, с. 20; Звєрєва, 2012, с. 20). Незважаючи на існування різних підходів до класифікації видів відповідальності, їх автори єдині у думці, що успішне виконання фахівцем професійних обов'язків значною мірою залежить від рівня його соціальної відповідальності (Колот, 2011, 
с. 8). Саме тому світова спільнота розглядає соціальну відповідальність показником соціального виміру всіх суб’єктів відповідальності та запроваджує на цій основі відповідні стандарти.

Як зазначено у Міжнародному стандарті ISO 26000:2010, соціальна відповідальність $є$ відповідальністю організації (особи) за вплив своїх рішень $\mathrm{i}$ дій на суспільство та довкілля через прозору та етичну поведінку, що: сприяє стійкому розвитку, здоров'ю та добробуту суспільства, враховує очікування заінтересованих сторін, відповідає існуючому законодавству та узгоджується 3 міжнародними нормами поведінки, узгоджується стратегією розвитку організації, інтегрована в діяльність всієї організації, реалізується на практиці взаємовідносин організації (Международный HR-стандарт SA 80001997 «Социальная ответственность», 1997). Зазначимо, що, незважаючи на вказане визначення соціальної відповідальності, вчені не дійшли згоди щодо ії змісту та суті. Так, Л. Білецька визначає соціальну відповідальність як обов'язок особи оцінити власні наміри та здійснювати вибір поведінки відповідно до норм, які відображають інтереси суспільного розвитку, а у випадку їх порушення обов'язок звітувати перед суспільством і нести покарання. Дещо більш детальне визначення соціальної відповідальності знаходимо у Р. Хачатурова та Р. Ягутяна, які під соціальною відповідальністю розуміють дотримання суб'єктами суспільних відносин вимог соціальних норм, а у випадках безвідповідальної поведінки, що не відповідає вимогам норм чи порушує суспільний порядок, вони зобов'язані нести додаткову відповідальність особистого чи майнового характеру. О. Плахотний вважає, що поняття соціальної відповідальності поєднує дві ії різні форми - суспільну (як реакцію суспільства на поведінку індивіда) та особисту відповідальність (як відповідь індивіда на вимоги суспільства). Автор підкреслює, що $з$ одного боку, суспільство покладає на індивіда обов'язок здійснювати соціально корисні вчинки, а 3 іншого - воно зобов'язане сприяти суб'єкту в реалізації ним своїх прав та обов'язків і несе за це відповідальність. Як зазначає О. Ростигаєв, соціальна відповідальність $\epsilon$ виразом всієї багатоманітності соціальних відносин та узагальненим виразом усіх форм відповідальності, а специфіка конкретних видів відповідальності обумовлена природою тих суспільних відносин, всередині яких вони виникли й існують у власній якісній визначеності. О. Поляков характеризує соціальну відповідальність як зовнішню негативну реакцію суспільства на дії суб'єкта, що порушують соціальні норми i комунікацію; легітимну соціальну відповідь на його неприпустиму поведінку через реалізацію принципу покарання. I. Семякін визначає соціальну відповідальність як обов'язок індивіда виконувати відповідні політичні, юридичні та моральні вимоги, що встановлюються суспільством, державою чи колективом. трактує соціальну відповідальність як діалектичний взаємозв'язок між особою та суспільством, що характеризується взаємними правами та обов'язками 3 виконання приписів соціальних норм та застосуванням різноманітних засобів впливу у разі їх порушення (Грищук, 2012; Кузьмін, 2016; Охріменко, 2015). Таким чином, вважаємо, що соціальна відповідальність - це морально-ціннісне стійке утворення, що сприяє усвідомленому відношенню особистості до інших 
людей, навколишнього середовища і проявляється у гуманістичній спрямованості iї вчинків та розумінні значущості їх наслідків.

Погоджуємось із О. Охріменко, Т. Івановою які виділяють такі характерні ознаки соціальної відповідальності: соціальне явище, наділене конкретноісторичним змістом; свідоме виконання обов'язку особи перед суспільством; веління совісті суб'єкта; інтегративна властивість, що виникає внаслідок синтезу особистістю усіх іiі моральних рис; осмислений рух свідомості, який перетворює можливість у реальність; містить ініціативний характер; надає перевагу суспільному суб'єкту, або індивідуальному суб'єкту, який трактується як представник суспільства чи соціальної групи; налагоджує компроміс між суспільними інтересами, цілями та індивідуальними, професійними, етичними й ін. прагненнями; відповідає очікуванням людей стосовно соціальної позиції суб'єкта у формуванні соціально визначених атрибутів конкретних соціальних груп; відсутність соціальної відповідальності передбачає осуд суспільством (суспільною групою або окремими членами суспільства) (Охріменко , 2015, с. 6).

Складовими соціальної відповідальності є суб'єкт (суспільство, держава, організація (служба), або окремий індивід (у нашому дослідженні - фахівець соціальної сфери)) і об'єкт (усі ті особи (соціальні групи), реалізації чиїх інтересів сприяє відповідальна поведінка суб'єкта) (Савченко, 2005, с. 59). Вважаємо, що суб'єктна і об'єктна складові соціальної відповідальності взаємо обумовлюють одна одну. Окрім того, варто зазначити, що соціальна відповідальність конкретного суб'єкта (фахівця соціальної сфери) може поширюватися не на всі об'єкти соціальної відповідальності. Тому повноту й ефективність соціальної відповідальності суб'єкта щодо об'єкта можна визначити за ступенем їх включення в спільну діяльність. У зв'язку 3 цим, науковці та практики розрізняють максимальний, мінімальний, припустимий й фактичний рівні соціальної відповідальності (Новікова, 2013, с. 116). За масштабом охоплення рівні соціальної відповідальності визначають як: відповідальність на макрорівні (перед жителями всієї країни у всіх іï проявах) - макровідповідальність, відповідальність на мезорівні (рівень поселення, регіону) - мезовідповідальність та відповідальність на мікрорівні (рівень конкретної особи (організації)) мікровідповідальність (Колот, 2012, с. 10). В означену класифікацію рівнів соціальної відповідальності ми пропонуємо ввести поняття «мегавідповідальність», або відповідальність на мегарівні (рівень корпорації, планети поселення), оскільки в період глобалізації саме соціальна відповідальність фахівців може суттєво впливати на систему міжнародних відносин і визначати тенденції розвитку національних економік та світу в цілому. Як правило, при оцінці рівня соціальної відповідальності застосовують поділ показників на групи (найчастіше - економічні (наприклад, розмір соціальних інвестицій на одного працівника, відношення соціальних інвестицій до прибутку та ін.), екологічні (кількість випадків перевищення екологічних норм, кількість порушень технологічних регламентів і ін.) та соціальні (дефіцит робочої сили, плинність кадрів і ін.) показники). Оскільки ті або інші соціально відповідальні дії не завжди приводять до очікуваного результату, вчені виділяють також 
реальну (приносить реальний ефект) і формальну (результат не той, що повинен був бути, результат відсутній зовсім) відповідальність (Новікова, 2013, с. 129).

На основі аналізу наукових досліджень А. Колот та І. Савченко приходимо до висновку про відсутність єдиного підходу до класифікації видів соціальної відповідальності. Як зазначають вчені, Н. Фокіна вважає, що соціальна відповідальність складається 3 моральної і правової відповідальності. На думку Н. Головко, окрім означених, важливим видом соціальної відповідальності $\epsilon$ політична відповідальність. Л. Грядунова розширює цей перелік громадянською, партійною, виробничою та сімейно-побутовою відповідальністю. О. Плахотний пропонує додати до вказаних видів економічну, національну та державну відповідальність. Р. Хачатуров вважає, що у суспільстві існує стільки видів соціальної відповідальності, скільки в ньому діє видів соціальних норм (Колот, 2012 , с. 9; Савченко, 2005, с. 61). Найбільш обгрунтованим, на нашу думку, є поділ В. Грищук соціальної відповідальності фахівця на неправову та правову відповідальність. Неправова відповідальність не має юридичного характеру та включає політичну, корпоративну, моральну, релігійну й інші види соціальної відповідальності. Усі вони мають пасивний характер, оскільки не передбачають вимог відповідної поведінки, а відображаються у демонстрації негативного ставлення через обмеження, відмову у спілкуванні чи дистанціювання щодо порушника. Правова соціальна відповідальність фахівця соціальної сфери настає у випадку порушення норм права. Вона має активний характер, оскільки передбачає активний психологічний вплив на порушника аж до застосування примусового фізичного впливу (Грищук, 2012, с. 18). Як зазначає О. Охріменко, соціальна відповідальність може мати дві форми реалізації: добровільну (виражену в обов'язку суб'єкта правомірною поведінкою виконувати приписи соціальних норм) і примусову (виражену в обов'язку порушника соціальних норм підпорядкуватися різноманітним заходам суспільного і державного примусу) (Охріменко, 2015, с. 48).

На основі аналізу дослідження О. Новікової можемо стверджувати, що соціальна відповідальність фахівця соціальної сфери визначається за двома групами критеріїв: об’єктивні критерії (відображають зумовленість дій суб'єкта зовнішніми соціальними вимогами, тобто, реальне включення фахівця у соціальні зв'язки та взаємовідносини) та суб’єктивні критерії (характеризують соціальні й морально-психологічні якості особистості фахівця як суспільної істоти та результату соціалізації, виявляють рівень усвідомлення нею власного обов'язку перед суспільством) (Новікова, 2013, с. 47).

Показники або рейтинги соціальної відповідальності фахівця соціальної сфери відображають рівень його соціальної активності в межах прийнятої системи оцінювання (Новікова, 2013, с. 63). Будь-яка система оцінювання соціальної відповідальності демонструє співвідношення соціальної активності 3 результатами реалізації принципів соціальної відповідальності, основними з яких $\epsilon$ принципи: гуманізму (передбачає визнання та дотримання прав людини); прозорості (означає відкритість процедури прийняття рішень); підзвітності (полягає у систематичній звітності про вплив своєї діяльності на інших і навколишнє середовище); поміркованості у прийнятті рішень (забезпечує 
збереження життя та здоров'я); патріотизму (полягає в усвідомленні цінності Батьківщини); обов'язку (передбачає наявність і виконання моральних зобов'язань); духовності (забезпечує гармонійний розвиток духовних засад людини); професійної компетентності (передбачає здобуття освіти, наявність відповідних знань, сформованість умінь і навичок, підвищення кваліфікації 3 відповідної галузі діяльності); працелюбності (полягає у позитивному ставленні до праці, що виражається через добросовісність, дисциплінованість, ініціативність, активність); творчої спрямованості (полягає у креативності, творчій ініціативі) (Вієвська, 2015; Шинкарук, 2002).

Відрадно, що сьогодні розроблено багато методик оцінювання кількісних та якісних показників соціальної відповідальності для використання у різних галузях діяльності, у тому числі - соціальній сфері, що слугуватиме предметом наших подальших досліджень.

\section{Висновки}

Таким чином, соціальна відповідальність $є$ надзвичайно актуальною у сучасному суспільстві, оскільки слугує гарантією його сталого економічного та соціального розвитку, покращення якості життя та удосконалення виробничих відносин. Вона $є$ комплексною категорією та передбачає наявність різноманітних форм і видів. У перспективі в соціальній відповідальності фахівця соціальної сфери акценти зміщуватимуться від індивідуальної й причинно-наслідкової реакції до його проспективної (відповідальності за майбутню поведінку) і перспективної (дії на упередження подій) діяльності та корпоративної відповідальності.

\section{Література.}

Амоша, О. (2011). Соціальна відповідальність в контексті розвитку людського потенціалу. Держава i суспільство. [Електронний ресурс]. Режим доступу: http://www.nbuv.gov.ua/portal/soc_gum/pubupr/2011- 1/doc/3/01.pdf. 122-27.

Вієвська, М. Г. (2015). Соціальна відповідальність сучасного фахівця як підгрунтя його продуктивної професійної діяльності. Наука і освіта. (9), 19-24.

Грищук, В. К. (2012). Соціальна відповідальність: навчальний посібник. Львів: Львівський університет внутрішніх справ, 152.

Новікова, О. Ф. (2013). Діагностика стану та перспектив розвитку соціальної відповідальності в Україні (експертні оцінки) : монографія / О.Ф. Новікова, М. С. Дейч, О. В. Панькова та ін.; НАН України, Ін-т економіки пром-сті. Донецьк, 296.

Звєрєва, I. Д. (2012). Енциклопедія для фахівців соціальної сфери ; за заг. ред. І. Д. Звєрєвої; М-во освіти і науки, молоді та спорту України, Ін-т проблем виховання НАПН України [та ін.]. Київ; Сімферополь: Універсум, 535.

Колот, А. М. (2011). Соціальна відповідальність людини як чинник стійкої соціальної динаміки: теоретичні засади / А. М. Колот // Україна: аспекти праці [Електронний ресурс] : наук.-екон. та сусп.-політ. журнал / Вид-во «Праця»; гол. ред. О. Варецька. (3), 3-9.

Колот, А. М. (2012). Соціальна відповідальність: теорія і практика розвитку : монографія; за наук. ред. д-ра екон. наук, проф. А. М. Колота. К.: КНЕУ, 501. 
Кузьмін, О. Є. (2016). Соціальна відповідальність : навч. посібн. Нац. ун-т «Львів. Політехніка». - Львів: Вид-во Львів. політехніки, 326.

Международный HR-стандарт SA 80001997 «Социальная ответственность». Сообщество HR-менеджеров [Електронний ресурс]. Режим доступу: http://www.hrportal.ru/article/mezhdunarodnyi-hr-standart-sa-80001997 sotsialnayaotvetstvennost $\% \mathrm{C} 2 \% \mathrm{BB}$.

Охріменко, О.О. (2015). Соціальна відповідальність. Навчальний посібник. Київ : Національний технічний університет України «Київський політехнічний інститут». 180.

Савченко, І. Г. (2005). Соціальна відповідальність в контексті розбудови соціальної держави в Україні. Актуальні проблеми державного управління: Зб. наук. пр. - Х.: Вид-во ХарРІ НАДУ «Магістр», (2(24)): У 2 ч. Ч. 1, 55-63.

Шинкарук, В.І. (2002). Відповідальність. Філософський енциклопедичний словник. Київ : Абрис, 742. 


\title{
SOCIAL RESPONSIBILITY OF THE SOCIAL SPHERE SPECIALIST AS AN IMPORTANT FACTOR OF RESULTUITABILITY OF HIS PROFESSIONAL ACTIVITY
}

\author{
Mykola Pihovskyi, Ph.D. student of Department of Social Pedagogy and Social Work \\ Ternopil National Volodymyr Hnatyuk Pedagogical University \\ Ternopil, Ukraine
}

\begin{abstract}
The article summarizes the scientific material about liability in general and about social responsibility of a specialist in the social sphere. It is noted that the social sphere, which satisfies the needs of the population in education, health care, cultural values, communal services, etc., increasingly affects on the production of material wealth through accelerating scientific and technological progress, creating the necessary prerequisites for raising the level of employment in social production and rational using personnel potential, providing an expanded reproduction of the workforce, improving the structure of the free working time. The importance of forming a social responsibility of a specialist in the social sphere for the fulfillment of his professional duties is substantiated. On the basis of the analysis of scientific research the content of the concepts of "responsibility» (as an awareness of the essence and significance of activities, actions of the person and their consequences for society) and «social responsibility» (as a conscious, voluntary fulfillment by the subjects of social relations of the regulations and social norms) are analyzed. It is indicated that the formation of social specialist responsibility in the Ukrainian social sphere is accompanied by a number of problems. It is characterized different levels (maximum, minimum, permissible and actual, as well as mega-, macro-, meso-, micro-), characteristic features, structure (subject and object), types (non-legal (includes state, civil, political, economic, moral, national, religious, industrial, family, etc.) and legal (legal) social responsibility), principles (humanism, transparency, accountability, moderation in decision-making process, patriotism, duty, spirituality, professional competence, creative orientation, hard-working) and forms (voluntary and forced) implementation of social responsibility specialist social services. Criteria (subjective and objective) and indicators of social responsibility are substantiated too. The prospects of development of social responsibility as a personality quality of a specialist in a social sphere are determined.
\end{abstract}

Key words: responsibility; social accountability; social sphere; specialist; professional activity; performance.

\section{References}

Amosha, O. (2011). Social Responsibility in the Context of Human Potential Development. State and Society. (pp. 122-127). Retrieved from http://www.nbuv.gov.ua/portal/soc_gum/ pubupr/2011- 1/doc/3/01.pdf (in ukr).

Hryshchuk, V. K. (2012). Social responsibility. Tutorial. Lviv, Ukraine: Lviv State University of Internal Affairs, 152 (in ukr).

Kolot, A. M. (2011). Social responsibility of man as a factor of sustainable social dynamics: theoretical foundations. «Pratsia», 3, 3-9 (in ukr).

Kolot, A. M. (2012). Social Responsibility: Theory and Practice of Development: Monograph. K.: KNEU, 501 (in ukr). 
Kuzmin, O. Ye. (2016). Social Responsibility: Textbook. Lviv, Ukraine: Lviv Polytechnic National University, 326 (in ukr).

International HR-standard SA 80001997 «Social Responsibility» / HR-Portal / Community of HR-managers. Retrieved from: http://www.hrportal.ru/article/mezhdunarodnyi-hr-standart-sa-80001997 sotsialnayaotvetstvennost $\% \mathrm{C} 2 \% \mathrm{BB}$ (in rus).

Novikova O. F. (2013). Diagnosis of the state and prospects of development of social responsibility in Ukraine (expert assessments): monograph. National Academy of Sciences of Ukraine, Donetsk, Ukraine, 296 (in ukr).

Okhrimenko O. O. (2015). Social responsibility. Tutorial. National Technical University of Ukraine, 180 (in ukr).

Savchenko I. H. (2005). Social Responsibility in the Context of Building a Social State in Ukraine. Actual problems of public administration: Collection of scientific works. «Mahistr», 2(24), 55-63 (in ukr).

Shynkaruk V. I. (2002). Responsibility // Philosophical Encyclopedic Dictionary. Kyiv, Ukraine, «Abrys», 742 (in ukr).

Viievska M. H. (2015). Social responsibility of a modern specialist as a basis for his productive professional activities. Nauka i osvita, 9, 19-24 (in ukr).

Zvierieva I. D. (2012). Encyclopedia for specialists in the social sphere. Ministry of Education and Science, Youth and Sports of Ukraine, Institute of Problems of Education of the National Academy of Pedagogical Sciences of Ukraine [and others]. Kyiv; Simferopol, Ukraine: Universum, 535 (in ukr). 